SALAM; Jurnal Sosial \& Budaya Syar-i

FSH UIN Syarif Hidayatullah Jakarta

Vol. 7 No. 8 (2020), pp. 707-722, DOl: 10.15408/sjsbs.v7i8.15959

\title{
Manajemen Komunikasi Keluarga Saat Pandemi COVID-19*
}

\author{
Ana Kuswanti ${ }^{1}$, Muqsith Abdul Munadhil'2, Anna Gustina Zainal ${ }^{3}$, Selly Oktarina ${ }^{4}$
}

1,2 Universitas Pembangunan Nasional Veteran, Jakarta

2 Peoples' Friendship University of Russia, Moscow

${ }^{3}$ FISIP Universitas Lampung, ${ }^{4}$ Universitas Sriwijaya, Palembang

d.

$\underline{10.15408 / \text { sjsbs.v7i8.15959 }}$

\begin{abstract}
This article wants to explain that the Coronavirus Disease or COVID-19 pandemic disrupts the structure of family life. Since the government suppressed physical distancing, it indirectly allowed almost 24 hours to be at home. The COVID-19 pandemic greatly tested family resilience. Positively, the impact of independent quarantine gives time to get to know each other deeply among family members. On the other hand, the more often family members meet increases boredom, which then causes friction to occur. This paper writes how the family communication management strategy when Pandemic COVID-19 to create a harmonious and prosperous family, conduct interpersonal communication, responsibility for the environment and family, intensity and direction of communication with a harmonious atmosphere, healthy parenting even in a physical atmosphere distancing or guarding the distance according to government recommendations.

Keywords: Family Communication Management; Covid-19 Pandemic; Family Resilience
\end{abstract}

\begin{abstract}
Abstrak
Artikel ini ingin menjelaskan bahwa pandemik Coronavirus Disease atau COVID-19 mendistrupsi tatanan kehidupan keluarga. Sejak pemerintah menekannya physical distancing atau penjagaan jarak secara tidak langsung memberikan waktu nyaris 24 jam berada di rumah. Pandemi COVID-19 sangat menguji ketahanan keluarga. Secara positif, dampak karantina mandiri memberi waktu untuk saling mengenal secara mendalam antar anggota keluarga. Disisi lain, semakin sering anggota keluarga bertemu meningkatkan rasa jenuh yang kemudian menimbulkan gesekan terjadi. Tulisan ini menulis bagaimana strategi manajemen komunikasi keluarga saat Pandemi COVID-19 sehingga tercipta keluarga yang harmonis dan sejahtera, melakukan komunikasi antar pribadi, tanggung jawab pada lingkungan dan keluarga, intensitas dan arah komunikasi dengan atmosfir yang harmonis, pola asuh hidup sehat walaupun dalam suasana physical distancing atau penjagaan jarak sesuai anjuran pemerintah.
\end{abstract}

Kata kunci: Manajemen Komunikasi Keluarga; Pandemik Covid-19; Ketahanan Keluarga

* Diterima: 12 April 2020, Revisi: 28 Juli 2020, Diterbitkan 12 Agustus 2020.

${ }^{1}$ Ana Kuswanti adalah Mahasiswa Doktoral IPB pada Program Studi Komunikasi Pembangunan Pertanian dan Pedesaan IPB dan Dosen Universitas Pembangunan Nasional Veteran Jakarta. Email: anakuswanti@upnvj.ac.id

${ }^{2}$ Munadhil Abdul Muqsith adalah Mahasiswa Ph.D pada Departemen Komunikasi Massa, RUDN University Moskow, Russia dan Dosen Universitas Pembangunan Nasional Veteran Jakarta.. Email: munadhil.muqsith@gmail.com

${ }^{3}$ Anna Gustina Zainal adalah Mahasiswa Doktoral IPB pada Program Studi Komunikasi Pembangunan Pertanian dan Pedesaan IPB dan Dosen FISIP Universitas Lampung. Email:anna.gustina@fisip.unila.ac.id

${ }^{4}$ Selly Oktarina adalah Mahasiswa Doktoral IPB pada Program Studi Komunikasi Pembangunan Pertanian dan Pedesaan IPB dan Universitas Sriwijaya Email: sellymus@yahoo.com 


\section{A. PENDAHULUAN}

Pandemik Coronavirus Disease atau COVID-19 telah mendistupsi kehidupan tatanan sosial umat manusia. Arif Satria (2020) mengistilahkan, wabah COVID-19 menginstall ulang tata seluruh kehidupan manusia ${ }^{5}$. Hanya dalam kurang tiga bulan, virus ini sudah menyebar hampir di seluruh negara di dunia dan menginfeksi 7.055.6196 ${ }^{6}$ orang, 403.755 meninggal dan 3.446.882 dinyatakan sembuh. Sedangkan di Indonesia berdasarkan data worldmeters.info pertanggal 07 Juni 2020, jumlah orang yang terinfeksi mencapai 31.186 orang dengan jumlah meninggal dan sembuh berturut-turut sebanyak 1.851 dan 10.498 .

Distrupsi COVID-19 menyebabkan krisis multi-dimensi. Bermula dari tragedi kemanusian yang menyebabkan kecemasan manusia terhadap kesehatan, meluas kepada sektor ekonomi, industri, pendidikan, keagamaan, pemerintahan, serta pangan dan badai berita palsu atau krisis infodemic ${ }^{7}$. Lebih dari 70 negara kemudian melakukan lockdown menyebabkan terpukulnya berbagai sektor ekonomi. Beberapa sektor yang terpukul keras misalnya seperti sektor jasa, terutama industri yang melibatkan interaksi fisik seperti perdagangan ritel, rekreasi dan perhotelan dan transportasi.

Implikasi ekonomi juga tidak bisa dianggap remeh. Salah satu dampak ekonomi yang begitu nyata adalah daya beli masyarakat menurun, pekerja dirumahkan, bahkan sampai diputus hubungan kerja (PHK), kemiskinan meningkat, mobilitas orang dan barang terganggu dan terdepresiasinya nilai tukar rupiah terhadap dollar Amerika sampai menyentuh Rp. 16.400-an per USD ${ }^{8}$.

Sesuai anjuran Badan Kesehatan dunia (WHO), Pemerintah membuat kebijakan Pembatasan sosial bersekala (PSBB) mengurangi penyebaran virus corona di beberapa provinsi yang tercap rawan atau dalam zona merah. Selain itu, antara lain melewati swakarantina atau diam di rumah atau stay at home untuk mengurangi perkumpulan yang menjadi penyebab cepatnya penyebaran virus ini antar manusia. Membatasi bertemu dengan orang, termasuk bekerja dari rumah istilah populernya work from home (WFH).

Seringnya berada di rumah berhari-hari sejak pemerintah menekankan physical distancing atau penjagaan jarak memberikan dampak nyata pada kehidupan keluarga. Sebagai unit terkecil dalam masyarakat, dampak pandemi COVID-19 bisa dilihat dari dua sisi, baik negatif maupun positif ${ }^{9}$. Secara positif, misalnya, masa karantina mandiri

${ }^{5}$ A. Satria, 2020, Install Ulang Tata Kehidupan. Media Indonesia. https://mediaindonesia.com/read/detail/308107-install-ulang-tata-kehidupan di akses 8 Juni 2020

${ }^{6}$ https://www.worldometers.info/coronavirus/ di akses 8 Juni 2020

${ }^{7}$ Muqsith, M., \& Muzykant, V. (2019). Effect Fake News for Democracy. Jurnal Cita Hukum, 7(3), 307-318. doi:https://doi.org/10.15408/jch.v7i3.12956

8 K.S.S. Hadinagoro, 2020, COVID-19 dan Dampak Multi-Dimensional, Perpustakaan Nasional https://www.perpusnas.go.id/news-detail.php?lang=id\&id=200509123514uCYGKgPxSb di akses 8 Juni 2020

9 Tim Cnn Indonesia, 2020, Dampak Positif-Negatif Pandemi pada Hubungan Keluarga, CNN Indonesia, $\quad$ https://www.cnnindonesia.com/gaya-hidup/20200514141751-284-503363/dampak-positifnegatif-pandemi-pada-hubungan-keluarga di akses 8 juni 2020 
secara tidak langsung memberikan waktu untuk lebih saling mengenal secara mendalam antar-anggota keluarga. Disisi lain, nyarisnya selama 24 jam berada di rumah rentan menimbulkan berbagai gesekan. Semakin sering anggota keluarga bertemu, semakin sering gesekan terjadi. Wabah COVID-19 juga sangat menguji ketahanan keluarga.

Pandemik COVID-19 mengajarkan kita memahami bagaimana seharusnya manajemen komunikasi keluarga. Tiap entitas keluarga harus mengerti peran dan tanggung jawabnya. Seorang bapak harus tahu perannya sebagai ayah dan pemimpin keluarga yang baik. Begitu juga ibu, harus tahu perannya sebagai sosok istri sekaligus ibu biologis bagi anak-anaknya. Begitu juga seorang anak, harus tahu bagimana peran nya sebagai anak dari kedua orangtuanya. Artikel ini akan menulis bagaimana manajemen komunikasi organisasi keluarga pada pandemik COVID-19.

\section{B. METODE PENELITIAN}

Untuk menguraikan masalah ini dibutuhkan sumber penelitian berupa bahan primer dan bahan sekunder berupa buku-buku, teks, dan artikel-artikel jurnal. Metode penelitian ini bersifat yuridis normative empiris dan jenis penelitian kualitatif.

\section{ANALISIS DAN PEMBAHASAN}

\section{Konsep Komunikasi Keluarga}

Konsep keluarga menurut sejumlah ahli adalah sebagai unit sosial-ekonomi terkecil dalam masyarakat yang merupakan landasan dasar dari semua institusi, merupakan kelompok primer yang terdiri dari dua atau lebih orang yang mempunyai jaringan interaksi interpersonal, hubungan darah, hubungan perkawinan, dan adopsi. Menurut U.S. Bureau of the Census Tahun 2000 (dalam puspitawati, 2003) keluarga terdiri atas orang-orang yang hidup dalam satu rumah tangga (Newman \& Grauerholz 2002; Rosen (Skolnick \& Skolnick 1997). Berdasarkan Undang-undang No 52 Tahun 2009 tentang Perkembangan Kependudukan dan Pembangunan Keluarga Pasal 1 Ayat (6) pengertian keluarga adalah unit terkecil dalam masyarakat yang terdiri dari suami isteri, atau suami, istri dan anaknya, atau ayah dan anaknya, atau ibu dan anaknya ${ }^{10}$.

Konsep Keluarga dalam Kitab Suci al Qur'an:

1. Firman Allah dalam Surat At-Tahrim Ayat 6: "Hai orang-orang yang beriman, peliharalah dirimu dan keluargamu dari api neraka yang bahan bakarnya adalah manusia dan batu; penjaganya malaikat-malaikat yang kasar, yang keras, yang tidak mendurhakai Allah terhadap apa yang diperintahkan-Nya kepada mereka dan selalu mengerjakan apa yang diperintahkan".

${ }^{10}$ Kuswanti, A., Saleh, A., Hubeis, A., Puspitawati, H., \& Muqsith, M. (2020). The Impact of Regulation Policy in Indonesia Against Women's Family Head. Jurnal Cita Hukum, 8(1), 103-122. doi:https://doi.org/10.15408/jch.v8i1.14264 
2. Firman Allah dalam Surat Al-Furqon: Ayat 74 "Dan orang-orang yang berkata: "Ya Tuhan kami, anugerahkanlah kepada kami istri-istri kami dan keturunan kami sebagai penyenang hati (kami), dan jadikanlah kami imam bagi orangorang yang bertakwa".

Keluarga juga seperti diamahkan oleh Undang-Undang Nomor 52 Tahun 2009 Tentang Perkembangan Kependudukan dan Pembangunan Keluarga: Bab II: Bagian Ketiga Pasal 4 Ayat 2, bahwa pembangunan keluarga bertujuan untuk meningkatkan kualitas keluarga agar dapat timbul rasa aman, tenteram, dan harapan masa depan yang lebih baik dalam mewujudkan kesejahteraan lahir dan kebahagiaan batin. Menurut Mattessich dan Hill (Zeitlin 1995), keluarga merupakan suatu kelompok yang berhubungan kekerabatan, tempat tinggal, atau hubungan emosional yang sangat dekat yang memperlihatkan empat hal (yaitu interdepensi intim, memelihara batasbatas yang terseleksi, mampu untuk beradaptasi dengan perubahan dan memelihara identitas sepanjang waktu, dan melakukan tugas-tugas keluarga).

Definisi lain menurut Settels (Sussman dan Steinmetz 1987), dua keluarga juga diartikan sebagai suatu abstraksi dari ideologi yang memiliki citra romantis, suatu proses, sebagai satuan perlakukan intervensi, sebagai suatu jaringan dan tujuan/peristirahatan akhir. Lebih jauh, Frederick Engels dalam bukunya The Origin of the Family, Private Property, and the State, yang mewakili pandangan radikal menjabarkan keluarga mempunyai hubungan antara struktur sosial-ekonomi masyarakat dengan bentuk dan isi dari keluarga yang didasarkan pada sistem patriarkhi (Thromi 1999).

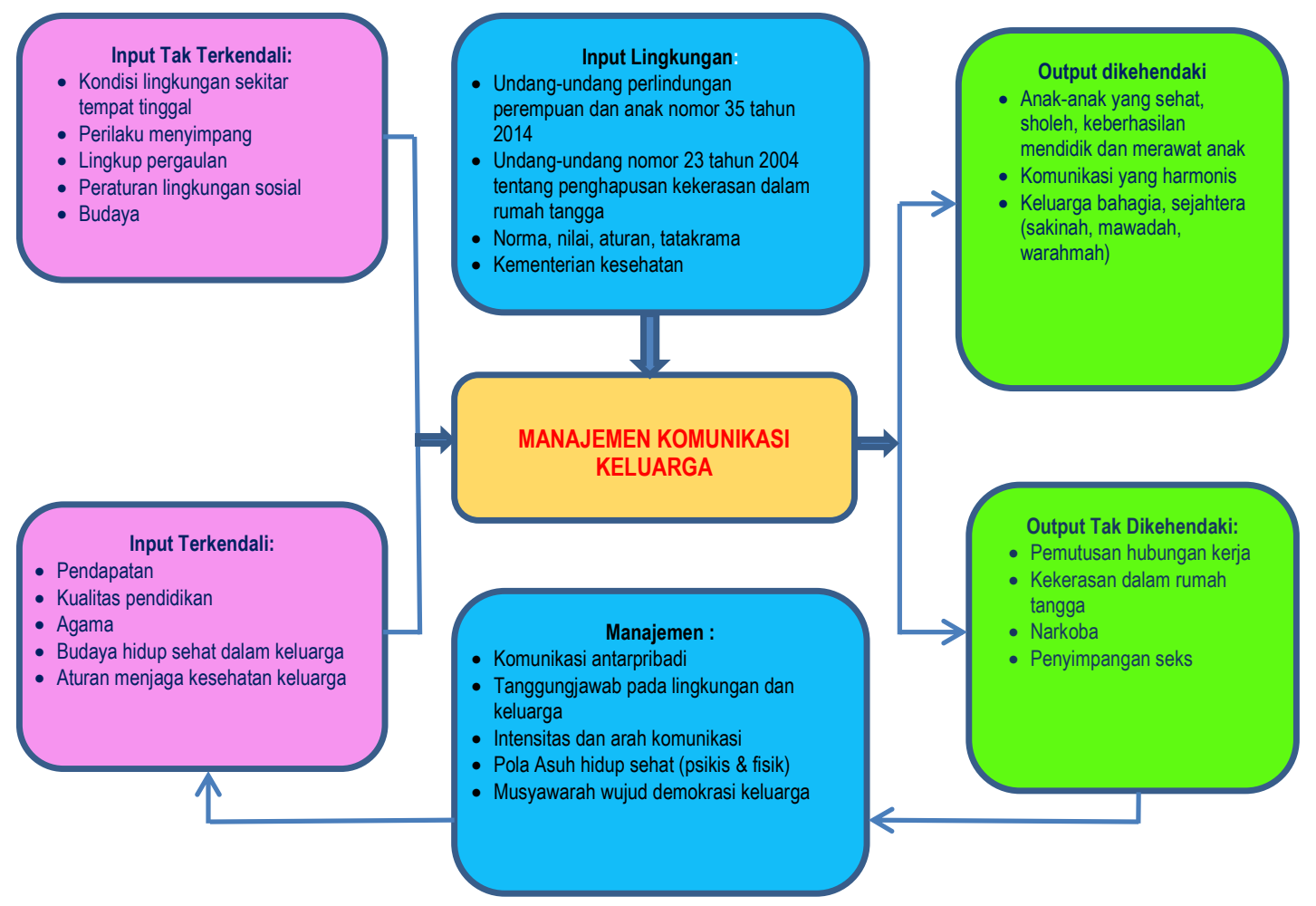

Gambar 1. Sistem manajemen komunikasi keluarga 


\section{Manajemen Tanggungjawab dalam Keluarga}

Langkah penting yang perlu dilakukan dalam menghadapi pandemi COVID-19 salah satunya dengan membentuk suatu atmosfir keluarga yang harmonis, untuk mewujudkannya memerlukan manajemen lingkungan keluarga, yaitu dengan melakukan sistem komunikasi yang dapat membentuk suatu pola hubungan yang harmonis. Pola komunikasi dimana masing-masing partisipan dapat beralih peran, diwaktu tertentu komunikator dapat berperan sebagai komunikan dan begitu sebaliknya, serta masing-masing partisipan memiliki hak suara yang sama, dan tidak boleh digantikan oleh orang lain Berlo dalam Mulyana (2007), dalam hal ini komunikasi yang terjadi dalam keluarga. Sumber adalah orangtua kepada anaknya ataupun anak kepada orangtua yang mempunyai pola-pola tertentu, dan biasanya pola komunikasi dalam keluarga akan membentuk budaya dalam keluarga ${ }^{11}$. Baik budaya berperilaku, pelaksanaan nilai-nilai, norma dan kepatuhan pada sistem yang berlangsung dalam keluarga. Fungsi Sosialisasi keluarga dalam keluarga merupakan suatu proses dimana orangtua melakukan penanaman nilai dan norma kepada anakanak atau anggota keluarga yang dicontohkan atau menjadi kebiasaan ayah dan ibu (orang tua) dalam mendidik, merawat, dan membesarkan anak-anaknya.

Sesuai dengan pemahaman bahwa keluarga sejahtera adalah keluarga yang dibentuk berdasarkan atas perkawinan yang sah, mampu memenuhi kebutuhan hidup spiritual dan materiil yang layak, bertaqwa kepada Tuhan Yang Maha Esa, memiliki hubungan yang serasi, selaras dan seimbang antar anggota dan antar keluarga dengan masyarakat dan lingkungan (Undang-Undang Republik Indonesia Nomor 52 tahun 2009). Serta pendapat Liliweri (1997) menjelaskan apabila antara anggota keluarga saling menanggapi pesan dan menerima pesan tersebut maka sebenarnya telah terjadi komunikasi antar pribadi dalam keluarga yang dialogis. Kegiatan umpan balik dari komunikasi dalam keluarga berfungsi sebagai unsur pemerkaya dan pemerkuat komunikasi antara anggota keluarga sehingga harapan dan keinginan anggota keluarga dapat dicapai ${ }^{12}$.

Keluarga memiliki fungsi dan peran yang dimainkan oleh setiap anggota keluarga. Peran dibangun dalam sebuah keluarga, berkembang dengan cara berkomunikasi seperti berdiskusi, berdialog, dan bernegosiasi antar anggota keluarga (Galvin et al. 2004). Peran keluarga dan aturan-aturan berkomunikasi pada suatu keluarga merupakan dua hal yang saling berkaitan dan saling memengaruhi. Peran setiap anggota keluarga yang dijalankan dengan baik akan berdampak baik pula terhadap kestabilan sistem keluarga. Pendapat lain oleh Cangara (2002) menjelaskan fungsi komunikasi dalam keluarga ialah meningkatkan hubungan insani (Human relation), menghindari dan mengatasi konflik-konflik pribadi dalam keluarga, mengurangi ketidak pastian sesuatu, serta berbagi pengetahuan dan pengalaman dengan orang lain ${ }^{13}$. Komunikasi dalam keluarga dapat meningkatkan hubungan

\footnotetext{
${ }^{11}$ Mulyana D. 2007. Ilmu Komunikasi Suatu Pengantar. Bandung(ID): PT. Remaja Rosdakarya. ${ }^{12}$ Liliweri A. M. S. 1997. Komunikasi Antar Pribadi. Bandung(ID): PT. Citra Aditya Bakti

${ }^{13}$ Cangara H. 2002. Pengantar Ilmu Komunikasi. Jakarta(ID): PT Raja Grafindo Persada.
} 
kemanusiaan diantar pihak-pihak yang berkomunikasi. Baik dalam kehidupan keluarga, lingkungan masyarakat, bahkan bernegara.

Pengertian manajemen menurut sistem informasi manajemen nasional Lemhanas (2015) adalah:“Usaha pendinamisasian, pengarahan, pengkoordinasian, proses pengambilan keputusan, penatalaksana pengendalian, pemeliharan dan pengembangan suatu organisasi dengan cara yang berdaya guna dan berhasil guna untuk mewujudkan organisasi"14. Manajemen keluarga setidaknya mengarah pada hal-hal sebagai berikut:

1. Perencanaan, untuk membina suatu keluarga perlu dilakukan perencanaan dan kesiapan yang matang, pada masa dalam perkawinan juga tetap memiliki perencanaan manajemen yang tepat, mau dibawa kemana arah perkawinannya, idealnya adalah menjadi keluarga yang sakinah mawadah warahmah.

2. Pengorganisasian, antara suami dan isteri terjadi pengaturan kerja dan tanggungjawabnya terhadap keberlangsungan rumah tangganya secara adil dan berimbang.

3. Pengarahan, mengomunikasikan segala sesuatu secara bersama antara suami dan isteri. Dinamika dalam rumah tangga sudah sewajarnya suami/ayah/lakilaki menjadi kepala keluarga dan memimpin bahtera rumahtangganya dengan baik, mengarah pada tujuan keluarga yang harmonis, sakinah, mawadah, warahmah. Disisi lain adakalanya peralihan atau pertukaran peran terjadi, sehingga harus dikomunikasikan secara baik diantara keduanya. Perempuan ibu rumah tangga bekerja mencari nafkah, dan suami atau ayah menjadi bapak rumah tangga (BRT).

4. Pengawasan, penting memiliki kemampuan untuk mengetahui letak kesalahan sehingga tindakan koreksi dapat dilakukan sedini mungkin. Pada fase ini, antara suami dan isteri saling mengontrol dan mengendalikan rencana yang ingin dicapai, suami setidaknya memiliki pekerjaan tetap karena harus mampu bertanggungjawab dalam memenuhi kebutuhan keluarga, atau begitu sebaliknya apabila terjadi peralihan peran.

5. Koordinasi, senantiasa mengomunikasikan dalam menjalankan tugas dan tanggungjawab antar suami dan isteri saling berkoordinasi, agar tujuan bersama yang akan dicapai dapat terwujud sesuai dengan harapan ${ }^{15}$.

Penjelasan selanjutnya dalam pola sistem berpikir keluarga (Iman, 2008) menguraikan pada management system thinking lebih menekankan pada kesadaran bahwa segala sesuatu berhubungan dalam satu rangkaian sistem. Berpikir sistem manajemen keluarga mengkombinasikan antara analytical thinking (kemampuan mengurai elemen-elemen suatu masalah) dengan synthetical thinking (memadukan elemen-elemen tersebut menjadi kesatuan). Jadi hubungan dalam keluarga lebih menenkankan pada kesadaran, bahwa hubungan manajemen komunikasi keluarga

${ }^{14}$ Lemhannas RI. 2015. "Modul bidang studi sistem manajemen nasional”. Ketahanan Nasional RI.

${ }^{15}$ Handoko, Hani T. 2001. Manajemen Personalia dan Sumber Daya Manusia. Yogyakarta(ID): BPFE. 
sangat penting dalam mengurai atau meminimalisir, serta memecahkan permasalahan yang dihadapi. Seriring dengan kondisi pandemi COVID-19 penting memberikan kesadaran kepada seluruh anggota keluarga akan bahaya COVID-19, sehingga perlu menyatukan visi dan misi dalam mencegah terpaparnya COVID-19 dalam keluarga, tentunya dengan mengacu pada standar pencegahan agar tidak terpapar COVID-19.

\section{Manajemen Organisasi Keluarga yang Terhindar dari Pandemi COVID-19}

Sesuai gambar pada black box yang merupakan pola dan kondisi keluarga, perlu dipahami bahwa manajemen organisasi keluarga, diawali dengan input lingkungan yang didasarkan pada peraturan dan perundang-undangan, yaitu Undang-undang No. 35 tahun 2014 tentang perubahan atas undang-undang nomor 23 tahun 2012 tentang perlindungan anak, undang-undang No. 23 Tahun 2004 sebagai pengganti undang-undang tentang penghapusan kekerasan dalam rumah tangga, norma, nilai, aturan dan tata karma.

Pengelolaan manajemen dan komunikasi dalam keluarga, tentu tidak terlepas dari komunikasi antarpribadi, yaitu komunikasi antara seluruh anggota keluarga yang dilakukan secara lebih mendalam, agar saling memahami antara anggota keluarga, Orangtua yakni ayah dan ibu serta anak-anaknya menjalin hubungan komunikasi antarpribadi sehingga terbina hubungan yang saling pengertian diantara seluruh anggota keluarga. Bahkan lebih mendalam dengan penetrasi sosial, seperti analogi bawang merah, komunikasi dari hal-hal yang umum, dangkal, kemudian mengomunikasikan sampai pada hal-hal yang sangat pribadi atau intim. Teori penetrasi sosial mempunyai peran yang besar dalam bidang psikologi dan komunikasi. Model teori penetrasi sosial menyediakan jalan yang lengkap untuk menggambarkan perkembangan hubungan interpersonal dan untuk mengembangkannya dengan pengalaman individu sebagai proses pengungkapan diri yang mendorong kemajuan hubungan. Oleh karena itu penting dalam keluarga melakukan komunikasi secara terbuka dan mendalam ${ }^{16}$.

Selain itu dalam manajemen keluarga tidak terlepas dari tanggungjawab, dimana tanggungjawab yang sangat mendasar adalah peranan orang tua yaitu ayah sebagai kepala keluarga, memenuhi semua kebutuhan keluarga; dan ibu sebagai ibu rumah tangga yang merawat dan mengurus rumah, mendidik serta membesarkan anak-anaknya. Atau jika terjadi peralihan atau pertukaran peran antara ibu sebagai pencari nafkah dan BRT tetap harus memerankan tanggungjawabnya secara baik. Merujuk pada pendapat Rogers (1983) tentang sistem komunikasi adalah suatu sistem yang terdiri atas individu-individu yang saling berhubungan, yang dilambangkan oleh arus komunikasi yang terpola. Salah satu cara untuk memahami perilaku manusia adalah dengan mengamati atau memahami hubungan-hubungan sosialnya yang tercipta karena adanya proses komunikasi interpersonal.

${ }^{16}$ Kadarsih R. 2009. Teori Penetrasi Sosial dan Hubungan Interpersonal. Jurnal Media Komunikasi dan Dakwah, Volume 10 (1): 53-66. Januari-Juni. 
Berdasarkan intensitas komunikasi dalam keluarga perlu ditingkatkan agar memberikan manfaat lebih bagi hubungan diantara seluruh anggota keluarga, sehingga meminimalisir kesalahpahaman diantara semua anggota keluarga (ayah, ibu, dan anak-anaknya). Setelah tahapan dalam manajemen keluarga komunikasi antar pribadi, tanggung jawab, intensitas komunikasi dilakukan, untuk dapat mencapai menjadi keluarga yang harmonis, sakinah mawadah warahma, maka perlu hal mendasar dalam mendidik anak, yaitu pola asuh yang benar. Intensitas komunikasi dilaksanakan harus seiring dengan arah komunikasi, menurut Freire (2005) mengemukakan bahwa komunikasi yang memberdayakan orang dan memiliki tujuan untuk membangun trust dan konsensus ${ }^{17}$.

Mengarah pada perihal komunikasi keluarga, terkait dengan kualitas dan kuantitas dalam berkomunikasi sangat penting untuk diperhatikan. Intensitas dan arah komunikasi yang dimungkinkan dapat terjadi pada pola asuh anak. Apabila anak tumbuh dalam suasana keluarga yang harmonis, senantiasa mendengar kata-kata yang positif dan penuh dengan dukungan sebagi contoh: lakukan apa yang kamu inginkan dengan penuh tanggungjawab/suportif, maka anak tumbuh dengan sikap-sikap positif. Begitu sebaliknya, jika anak tumbuh dalam suasana konflik, sering mendengar pertengkaran, kalimat larangan, disepelekan, diacuhkan, maka anak akan membentuk peribadi yang suka melawan. Didasarkan pola asuh dalam mendidik dan mengajarkan perilaku dalam kehidupan, sehingga jika pola asuh baik, maka akan terbentuk pribadi yang baik dan kuat, tetapi jika pola asuh diskriminasi, tidak dengan kasih sayang, maka yang terjadi adalah terbentuk pribadi yang mengarah negative, pemberontakan, dan pembangkangan.

Meningkat pada manajemen yang terakhir yaitu dalam hal pemecahan permasalahan dilakukan dengan cara musyawarah mufakat, atau secara kekeluargaan, sehingga masing-masing memiliki hak dalam mengeluarkan pendapatnya untuk menghasilkan titik temu sebagai solusi dalam pemecahan masalah yang ada. Sistem demokrasi dapat diterapkan dalam manajemen komunikasi keluarga.

Menjelaskan lebih lanjut mengenai input tak terkendali, merupakan suatu keadaan dimana terjadi diluar kendali diri kita, kondisi lingkungan sekitar tempat tinggal, dimana setiap individu dalam keluarga yang tinggal pada suatu lingkungan tentu saja tidak dapat secara sepenuhnya dapat mengontrol dan mengendalikan keadaan lingkungan sekitar kita tinggal seperti keinginan kita sendiri. Terkadang terdapat perilaku yang menyimpang yang terjadi karena pengaruh lingkungan. Hal tersebut terjadi bisa saja dari akibat segmen pergaulan yang kurang baik. Meskipun sudah terdapat peraturan pada lingkungan sosial, tetapi masih seringkali tidak dapat dihindari terjadi pelanggaran norma, aturan, nilai ataupun tatakrama, serta terkadang membentuk budaya baru, atau juga melanggar kebisaaan atau budaya yang sudah berlangsung selama ini yang tak terkendali dan terkadang cenderung kearah perilaku yang menyimpang.

\footnotetext{
${ }^{17}$ Freire P. 2005. Pedagogy of The Opressed. New York(US): Continuum.
} 
Kebiasaan-kebiasaan yang dilakukan dan sering berulang dapat membentuk suatu budaya. Jika input tak terkendali terkait mewabahnya COVID-19 memasuki area lingkungan tempat tinggal, maka hal tersebut hanya akan dicegah penyebarannya dengan beberapa rangkaian usaha seperti pola hidup sehat, makan makanan bergizi yang seimbang, berolah raga secara teratur, jaga jarak fisik, diam dirumah, dan bekerja dari rumah sesuai himbauan dan arahan dari pemerintah. Tetapi yang sangat berperan besar dan mendasar adalah budaya hidup sehat, hal inilah yang dapat menyeimbangkan input tak terkendali. Khususnya peran ibu rumah tangga atau sebaliknya peran BRT sangat berpengaruh terhadap keberlangsungan hidup sehat dalam keluarga. Orang tua adalah suritauladan, sehingga anak dapat mencontoh perilaku positif kedua orang tuanya.

Berdasarkan kondisi dimana terdapat input terkendali, yaitu apa yang dikendalikan dan diharapkan dapat terwujud, seperti antara suami dan isteri terjalin komunikasi yang baik, keduanya dapat memenuhi tanggungjawabnya baik secara materi maupun immateri, yaitu diwujudkan adanya kelengkapan akan sarana dan prasarana seluruh kebutuhan keluarga dapat terpenuhi dengan baik. Apabila isteri turut bekerja, tetapi suami tetap merupakan penopang tanggungjawab nomor satu dalam memenuhi tanggungjawab kebutuhan keluarga. Akan tetapi apabila terjadi peralihan dan pertukaran peran, maka BRT harus pula mampu melaksanakan tanggungjawabnya dalam menjaga, merawat, dan mendidik anaknya serta rumah tangganya dengan baik, seperti halnya jika diperankan oleh ibu rumah tangga ${ }^{18}$. Oleh karena pada setiap tanggungjawab memiliki konsekuensi. Hal demikian yang saat ini dialami beberapa rumah tangga di masa pandemi COVID-19.

Kondisi normal sebelum pandemi COVID-19, umumnya tanggungjawab utama isteri adalah, merawat rumah tangganya, menjaga dan merawat harta suami, mendidik, mengasuh, dan merawat anak-anaknya, dengan demikian pembagian tanggungjawab juga seimbang. Namun dengan adanya pandemi COVID-19, terjadi kondisi dimana tidak sedikit para suami sebagai kepala keluarga mengalami pemutusan hubungan kerja, sehingga tidak sedikit pula yang mengalami peralihan peran suami menjadi BRT. Oleh karena itu, hubungan antara suami dan isteri memiliki komitmen dan kualitas inovasi dalam memperbaiki hubungan secara besar hati. Perlu mengutamakan kualitas pendidikan, terutama pendidikan dalam keluarga (nilai, moral, tatakrama, ettitude, perilaku), pendidikan secara formal disekolah, penanaman nilai-nilai agama (orang tua sebagai suri tauladan) memberikan contoh senantiasa taat dan disiplin dalam beribadah, mengajak anak-anaknya untuk selalu melaksanakan syariat dalam agamanya.

Menjaga dan melestarikan budaya keluarga, tidak melupakan tradisi dan kebiasaan-kebiasaan yang baik, dan memiliki unsur edukasi guna tetap menjadikan keluarga adalah tempat ternyaman untuk mendidik anak-anak. Serta aturan-aturan

${ }^{18}$ Kuswanti, A., Saleh, A., Hubeis, A., Puspitawati, H., Muzykant, V. \& Muqsith, M (2020). Effect of Group Participative Communication Towards Pekka Economic Empowerment. International Journal of

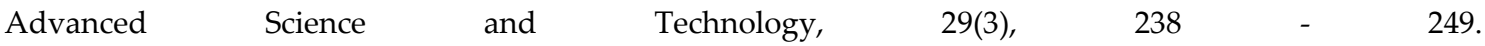
http://sersc.org/journals/index.php/IJAST/article/view/3912 
dalam keluarga yang selalu tetap dipatuhi, menjadikan kebiasaan yang positif dalam keluarga. Membiasakan dan menumbuhkan pada anak untuk senantiasa memiliki rasa tanggungjawab, mentaati aturan yang berlaku dimasyarakat dan keluarga, bertindak dengan didasari akhlak yang baik.

Menjaga kualitas, kuantitas, intensitas, understanding, sehingga terwujud hubungan yang harmonis. Diantara suami dan isteri melakukan kerjasama secara sinergi dalam menjaga keutuhan rumahtangga atau keluarganya, antara orang tua dan anak juga terjalin hubungan yang harmonis. Kerjasama dan bertanggungjawab dalam keluarga, menjaga, merawat, serta mendidik anak-anaknya. Apabila pembagian tanggungjawab yang seimbang, maka dimungkinkan lebih cenderung terwujud. Sebagai suatu output yang dikehendaki, maka antara suami dan isteri melakukan komunikasi dengan usaha untuk kesejahteraan keluarga. Melakukan tanggungjawab sebagai orangtua dengan memberikan perlakuan yang harmonis, adil, beradab, dalam mendidik anak-anaknya.

Berlanjut pada tahapan Output Dikehendaki, seperti dimasa pandemi COVID19, keluarga terjaga dari terpapar wabah COVID-19, anak-anak dididik untuk senantiasa hidup dengan pola yang sehat. Menerapkan nilai-nilai agama, karena agama apapun mengajarkan pola hidup bersih, sehat, seimbang. Hidup dengan tidak berlebihan makan makanan yang cukup seimbang dan sehat, olah raga yang cukup dan teratur, istirahat yang cukup secara terukur. Sehingga apabila anak-anaknya tumbuh dengan akhlak yang mulia, orang tua juga memberikan suri tauladan yang baik, maka akan tercipta keluarga yang bahagia dan sejahtera, karena orang tua juga bertanggungjawab penuh dalam memenuhi semua kebutuhan anak-anaknya, baik materiil dan nonmateriil. Terwujudlah suatu keluarga yang SAMAWA (sakinah, mawadah, dan warahmah). Sebagai contoh output dikehendaki cerminan pola asuh hidup sehat secara mental akan menghasilkan output yang positif, yakni apabila anak hidup dalam toleransi, membentuk pribadi yang sabar; Bila anak hidup dengan diberi semangat, maka ia mempunyai harga diri; Bila anak hidup dalam pujian, maka ia dapat lebih menghargai orang lain; Bila anak hidup dengan kejujuran, maka ia belajar tentang sikap keadilan; Bila anak hidup dalam rasa aman, maka ia belajar mempercayai orang lain; Bila anak hidup dengan penuh cobaan, maka ia belajar menjadi diri yang mandiri; Bila anak hidup dalam pengakuan dan persahabatan, maka ia belajar mencintai sesama dalam hidup ini.

Karena anak-anak tumbuh dan belajar dari lingkungan keluarga dan masyarakat. Oleh karena itu penting khususnya bagi orang tua untuk senantiasa bersikap dan berperilaku yang sarat dengan memberikan contoh positif. Maka anak akan memiliki ettitude yang baik, sesuai dengan harapan dari orang tuanya. Selain itu sebagai orang tua sudah seharusnya terbiasa bersikap terbuka dalam menghadapi permasalahan yang timbul, mengajak anak untuk berdiskusi atas permasalahan yang sedang dihadapi, menggunakan sistem demokrasi dan keterbukaan dalam keluarga, sehingga semua permasalahan mendapatkan solusi dan dapat dipecahkan dengan baik, tanpa menimbulkan suatu konflik yang baru. 
Sebagai tahapan pada black box yang terakhir yaitu output tak dikehendaki, dimana hal yang tidak diinginkan dimungkinkan terjadi dalam suatu rumah tangga dimasa pandemi COVID-19 saat ini terjadi pemutusan kerja secara masal, kondisi tersebut dapat merubah tatanan dan kebiasaan dalam keluarga. Hal tersebut dapat berakibat terjadi menipisnya anggaran dalam memenuhi kebutuhan rumah tangga, kondisi demikian secara otomatis dapat memengaruhi kondisi kesehatan psikologis. Apabila kondisi psikologis tidak seimbang, maka juga berakibat memengaruhi kesehatan secara fisik. Banyak hal yang terjadi akibat terdampak COVID-19, meningkatnya kasus kekerasan dalam rumah tangga (KDRT), hal tersebut dapat terjadi baik yang dilakukan oleh suami atau oleh isteri. Kemudian penyimpangan yang tak dikendaki dan rawan terjadi akibat salah pergaulan atau coba-coba yaitu penyalahgunaan obat terlarang (narkoba), dapat terjadi bukan saja sama anak karena salah pergaulan, ayah atau ibupun memiliki peluang dalam penyalahgunaan narkotika. Dan yang juga tidak kalah memprihatinkan adalah penyimpangan perilaku seks, yang terjadi kadang baik dilakukan oleh ayah, ibu atau anak.

Berdasarkan kondisi, maka dalam suatu rumah tangga juga akan muncul halhal yang diluar kendali (input tak terkendali), hal ini akan muncul seiring dengan kondisi lingkungan, baik lingkungan sosial secara umum, atau lingkungan dimana mereka tinggal. Sehingga dibutuhkan komitmen keluarga yang positif agar input tak terkendali masih mengarah pada hal-hal yang positif. Selanjutnya dalam keluarga terdapat pengembangan inovasi keluarga, biasanya hal ini terjadi karena adanya pengaruh informasi teknologi yang digunakan, bagaimana anggota keluarga dalam mengakses informasi dan terterpa informasi, apakah lebih pada hal-hal informasi yang positif atau hal yang negative, sehingga begitu sebaliknya dampak yang akan muncul positif atau negative. Bagaimana menfilter informasi bagi seluruh anggota keluarga (berita bohong atau realitas). Misalnya dengan adanya berita terkait pandemi COVID19, karena terterpa begitu banyaknya informasi terpaparnya anggota masyarakat akibat tidak mampu membatasi kontak fisik, sehingga penularannya sangat cepat. Melihat dan mendengar informasi tersebut kemudian mengalami kecemasan yang berlebihan atau parno. Sehingga penting dalam memilih informasi yang memiliki keakuratan data. Penting memberikan edukasi kepada anak terkait pemanfaatan teknologi informasi. Ciptakan anak agar mampu menghadapi kondisi baik lingkungan sosial (sekolah, bermain) atau lingkungan dimana tinggal, mampu beradaptasi dengan baik, atau justru menimbulkan dampak positif atau negative, apabila hal yang positif maka akan menghasilkan anak-anak yang berkualitas, anak akan tumbuh sesuai dengan apa yang diharapkan oleh kedua orangtuanya.

Selain hal tersebut datas, terdapat pula input tak terkendali lainnya akibat dari kebiasaan yang kurang disadari dalam berkomunikasi secara tidak tepat, sehingga membentuk kepribadian atau karakter anak yang negatif, seperti Bila anak hidup dalam kritikan, ia mudah menyalahkan orang lain; Bila anak hidup dimusuhi, ia memiliki keberanian untuk melawan; Bila anak hidup dalam ejekan, maka ia menjadi kurang percaya diri; Bila anak dalam suasana memalukan, ia mudah menyalahkan diri sendiri. Berdasarkan rangkaian penjelasan black box diatas, terdapat pelajaran yang dapat dipetik, perilaku merupakan cerminan dari perbuatan, apabila berbuat baik, 
maka akan menuai hasil yang positif, begitu sebaliknya pada hal yang negatif. Oleh karena itu, agar hal yang negative dan menyimpang tidak terjadi dalam sistem komunikasi keluarga, dibutuhkan kesadaran yang tinggi oleh seluruh anggota keluarga, serta manajemen yang tepat agar tujuan menjadi keluarga yang harmonis, sakinah mawadah warahmah dapat terwujud.

\section{Manajemen Sistem Komunikasi dalam Keluarga yang Terhindar Dari Pandemi COVID-19}

Kenyataan pada kasus ibu berperan ganda sebagai ibu dan sekaligus ayah dalam memenuhi semua kebutuhan dan tanggungjawab kepada anak-anaknya. Sistem komunikasi dan manajemen keluarganya tidak dapat berlangsung dengan baik, dikarenakan sosok ayah tidak ada lagi. Sistem komunikasi dalam keluarga hanya dapat dilakukan oleh ibu yang juga berperan ganda sebagai ayah, sehingga semua keputusan, tanggungjawab, memenuhi semua kebutuhan keluarga, dalam merawat, mendidik, membesarkan anak-anaknya dilakukan sendiri. Disisi lain ayah sebagai BRT sangat dimungkinkan wibawa sebagai seorang ayah akan menurun, baik dimata anak maupun kerabat keluarga, serta lingkugan. Karena belum semua masyarakat dapat menerima bahwa seorang ayah menjadi BRT.

Orang tua bekerja khususnya Ibu bekerja sering kali merasa bersalah ketika harus meninggalkan anak di rumah. Atau sebaliknya suami merasa bersalah karena menjadi BRT, kurang merasa bertanggung jawab, merasa tidak sempurna sebagai pria, wibawanya menjadi turun dimata isteri, kerabat keluarga, dan anak. Tidak perlu khawatir, dengan cara yang tepat, tetap bisa menjadi orang tua yang membesarkan anak dengan baik meskipun bekerja atau beralih peran dalam keluarga. Tentu ada akibat yang timbul ketika seorang ibu sibuk dengan pekerjaannya, atau ayah menjadi BRT. Guna mewujudkan manajemen jaringan komunikasi keluarga agar tercipta keluarga yang harmonis dan sejahtera terhindar dari pandemi COVID-19, maka diperlukan beberapa cara yang bisa ditempuh oleh ibu yang bekerja atau ayah sebagai BRT adalah :

1. Manajemen waktu dengan baik; hubungan suami, isteri dan anak memerlukan waktu yang berkualitas untuk berkumpul secara fisik. Waktu yang dibutuhkan tidak perlu lama, yang penting suami, isteri konsisten meluangkan waktu bersama anak setiap hari. Bagi ibu yang bekerja, sedapat mungkin mendapatkan pekerjaan di lingkungan yang ramah terhadap keluarga. Maksudnya disini adalah mencari tempat kerja yang memikirkan keadaan keluarga, contohnya: jam kerja yang fleksibel bagi orang tua bekerja khususnya perempuan, memberikan cuti hamil yang ideal, adanya tempat penitipan anak di tempat kerja dan tidak banyak perjalanan bisnis keluar kota/negeri. Dengan fleksibilitas dan pengertian yang diberikan oleh perusahaan tempat kerja, kita bisa memanfaatkan waktu tersebut untuk keluarga.

2. Jadikan waktu dengan anak sebagai pertemuan yang berkualitas; antara suami, isteri dan anak memiliki quality time. Hal yang dapat dilakukan saling 
berkomunikasi dalam suasana penuh kehangatan saat di rumah, menanyakan kejadian atau pengalaman yang dialami anak dihari itu, menjadi pendengar yang baik, berikan sentuhan fisik kepada anak seperti mengelus kepalanya, dan sisihkan juga waktu untuk membimbingnya belajar.

3. Jalin komunikasi yang baik dengan pihak yang mengurus anak; saat bekerja, seorang Ibu biasa menitipkan anak kepada pengasuh, entah itu baby sitter, nenek ataupun sanak keluarga lainnya. Komunikasi yang baik sangat berpengaruh terhadap pelayanan kasih sayang sang pengasuh terhadap anak Anda, visi dan misi Anda dalam mendidik anak pun setidaknya akan dapat diterjemahkan oleh pengasuh itu sendiri.

4. Jangan ganti kasih sayang dengan uang; sebagai orang tua, janganlah menggunakan uang sebagai pengganti waktu ataupun kasih sayang. Bekali anak dengan pemikiran sesuatu yang diperoleh melalui bekerja akan terasa lebih bernilai.

5. Pengawasan anak itu perlu; penelitian menunjukkan bahwa anak yang bermasalah mayoritas berasal dari keluarga yang kurang mengawasi anaknya. Sangat penting bagi orang tua untuk mengetahui dimana anaknya, sedang bersama siapa dan berbuat apa.

\section{KESIMPULAN}

Implementasi manajemen komunikasi keluarga dan berpikir sistem dalam mengelola keluarga agar tetap harmonis sangat penting pada saat pandemi COVID-19. Tetap menjaga input terkendali (pendapatan terjaga, kualitas pendidikan anak tetap terlaksana sesuai target, pendidikan agama dapat lebih diperdalam, tercipta budaya hidup sehat dalam keluarga). Senantiasa menjaga komunikasi antar pribadi, saling bertanggungjawab dalam menjaga kebersihan diri dan keluarga dengan pola hidup yang sehat, serta terbuka dalam mengomunikasikan segala permasalahan yang ada dalam keluarga. Mengarahkan terwujudnya output yang dikehendaki seperti; anakanak terawat baik secara fisik maupun mental, tercipta keluarga yang SAMAWA.

Kondisi keluarga dan sistem komunikasi yang tidak tepat dalam keluarga, akan menimbulkan dampak negatif dan positif. Dampak negatif seperti; Bila anak hidup dalam kritikan, maka ia belajar menyalahkan orang lain; Bila anak hidup dimusuhi, maka ia belajar untuk melawan; Bila anak hidup dalam ejekan, maka ia belajar jadi pemalu; Bila anak dalam suasana memalukan, maka ia belajar menjadi orang yang bersalah. Dampak positif, seperti: Bila anak hidup dalam toleransi, maka ia belajar menjadi sabar; Bila anak hidup dengan diberi semangat, maka ia belajar punya harga diri; Bila anak hidup dalam pujian, maka ia belajar menghargai orang lain; Bila anak hidup dengan kejujuran, maka ia belajar tentang keadilan; Bila anak hidup dalam rasa aman, maka ia belajar memercayai orang lain; Bila anak hidup dengan penuh cobaan, maka ia belajar menjadi dirinya sendiri; Bila anak hidup dalam pengakuan dan persahabatan, maka ia belajar mencintai sesama dalam hidup ini. 
Memenuhi harapan dalam mewujudkan manajemen komunikasi keluarga agar tercipta keluarga yang harmonis dan sejahtera, maka diperlukan beberapa cara yang bisa ditempuh oleh ibu yang bekerja adalah: (1) Manajemen waktu dengan baik; (2) Jadikan waktu dengan anak sebagai pertemuan yang berkualitas; (3) Jalin komunikasi yang baik dengan pihak yang mengurus anak; (4) Jangan ganti kasih sayang dengan uang; dan (5) Sangat penting dilakukan pengawasan pada anak. Sehingga sangat perlu dan penting memberikan perhatian yang cukup kepada anak, karena biasanya anak yang bermasalah mayoritas berasal dari keluarga yang kurang mengawasi anaknya. Sangat penting bagi orang tua untuk mengetahui dimana anaknya, sedang bersama siapa dan berbuat apa.

\section{REFERENSI:}

Cangara H. 2002. Pengantar Ilmu Komunikasi. Jakarta(ID): PT Raja Grafindo Persada.

Freire P. 2005. Pedagogy of The Opressed. New York(US): Continuum.

Galvin, KM, Bylund, CL \& Brommel, BJ 2004, Family Communication: Cohesion and Change (6th ed.), Pearson Education, New York.

Handoko, Hani T. 2001. Manajemen Personalia dan Sumber Daya Manusia. Yogyakarta(ID): BPFE.

Iman. 2008. Berpikir Kritis: Sebuah Pengantar. Jakarta(ID): Erlangga

Kadarsih R. 2009. Teori Penetrasi Sosial dan Hubungan Interpersonal. Jurnal Media Komunikasi dan Dakwah, Volume 10 (1): 53-66. Januari-Juni. http://ejournal.uin-suka.ac.id/dakwah/jurnaldakwah/article/view/414/391.

Kuswanti. 2017. Pola Asuh Anak sebagai cerminan perilaku, Majlis ilmu: Krukut

Lemhannas RI. 2015. "Modul bidang studi sistem manajemen nasional". Ketahanan Nasional RI.

Liliweri A. M. S. 1997. Komunikasi Antar Pribadi. Bandung(ID): PT. Citra Aditya Bakti

Mulyana D. 2007. Ilmu Komunikasi Suatu Pengantar. Bandung(ID): PT. Remaja Rosdakarya.

Rangkuti F. 2001. Measuring Customer Satisfaction, Jakarta(ID):.Penerbit PT. Gramedia Pustaka Utama,

Rogers, Everett M., 1983, Diffusion of Innovations. London(ING): The Free Press.

Satria A. 2020. Install ulang tata kehidupan manusia karena mewabahnya COVID-19. Rektor Institut Pertanian Bogor (IPB) di Media Indonesia (28/04/2020).

[Seknas Pekka] Sekretariat Nasional Perempuan Kepala Keluarga. 2015. Profile Pemberdayaan Perempuan Kepala Keluarga. [diunduh 2020 juni 04]. Tersedia pada http://seknas@ PEKKA.or.id 
Wijananto A. 2018, makin banyak pria bapak rumah tangga di Indonesia. detiknews 24/nov/2018. https://news.detik.com/abc-australia/d-4315033/makin-banyakpria-jadi-bapak-rumah-tangga-di-indonesia

Muqsith M.A., Muzykant V.L., Kuzmenkova K.E. (2019). Cyberprotest: new media and the new social movement in Indonesia // RUDN Journal of Studies in Literature and Journalism. - 2019. - Vol. 24. - N. 4. - P. 765-775. doi: 10.22363/2312-92202019-24-4-765-775

Muqsith M.A. (2019). The Relationship Of Political Socialization Messages Relations In Social Media Twitter With The Image Of PKS. (Study: Political Socialization PKS Through @PKSejahtera Account). Jurnal Ilmu Komunikasi Ekspresi dan Persepsi. 2019. Vol 2 No. 1 P. 3-12. Doi: http://dx.doi.org/10.33822/jep.v2i1.972

Muqsith, M., \& Muzykant, V. (2019). Effect Fake News for Democracy. Jurnal Cita Hukum, 7(3), 307-318. doi:https://doi.org/10.15408/jch.v7i3.12956

Kuswanti, A., Saleh, A., Hubeis, A., Puspitawati, H., \& Muqsith, M. (2020). The Impact of Regulation Policy In Indonesia Against Women's Family Head. Jurnal Cita Hukum, 8(1), 103-122. doi:https://doi.org/10.15408/jch.v8i1.14264

Muzykant V.L., Muqsith M.A., (2020) Media Education (Mediaobrazovanie) ISSN 19944195, E-ISSN 1994-4195, 2020, 60(1): 166-178. DOI: 10.13187/me.2020.1.166

Kuswanti, A., Saleh, A., Hubeis, A., Puspitawati, H., Muzykant, V. \& Muqsith, M (2020). Effect of Group Participative Communication Towards Pekka Economic Empowerment. International Journal of Advanced Science and Technology, 29(3), 238 - 249. http://sersc.org/journals/index.php/IJAST/article/view/3912

Kuswanti, A., Saleh, A., Hubeis, A., Puspitawati, H., \& Muqsith, M. (2020). The Journal of Social Sciences Research ISSN(e): 2411-9458, ISSN(p): 2413-6670 Vol. 6, Issue. 3, pp: 293-299, 2020. DOI: doi.org/10.32861/jssr.63.293.299

A. Satria, 2020, Install Ulang Tata Kehidupan. Media Indonesia. https://mediaindonesia.com/read/detail/308107-install-ulang-tata-kehidupan 
Ana Kuswanti, Muqsith Abdul Munadhil, Anna Gustina Zainal, Selly Oktarina 